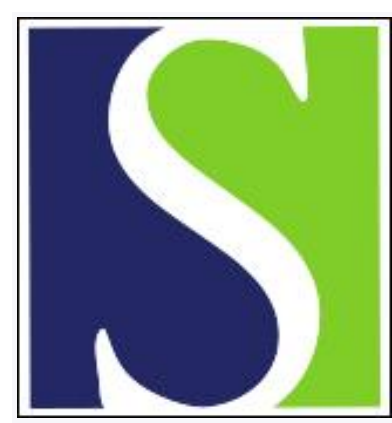

Scand J Work Environ Health 1996;22(5):325-331

https://doi.org/10.5271/sjweh.149

Issue date: Oct 1996

Evaluation of selected publications on reference values for lead in blood

by Gerhardsson L, Kazantzis G, Schütz A

Key terms: inorganic lead

This article in PubMed: www.ncbi.nlm.nih.gov/pubmed/8923604

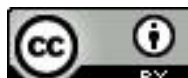




\title{
Evaluation of selected publications on reference values for lead in blood
}

\author{
by Lars Gerhardsson, MD,' George Kazantzis, MD, ${ }^{2}$ Andrejs Schütz, PhD'
}

\begin{abstract}
Gerhardsson L, Kazantzis G, Schütz A. Evaluation of selected publications on reference values for lead in blood Scand J Work Environ Health 1996;22:325-31.

As a part of the global Tracy project, whose aim is to define metal concentrations in tissues and body fluids of reference populations, more than 1000 papers published from 1980 to 1994 were scrutinized that presented tentative reference values for lead in blood in occupationally unexposed adult populations. Ten studies exemplifying criteria for proper sampling, analysis and data treatment are presented and discussed. Levels of lead in blood are influenced by numerous factors. Accordingly, a wide variation in blood lead concentrations was observed. As an example, in a global study in 1983 of nonsmoking female schoolteachers, the geometric mean value for lead in blood varied from $52 \mu \mathrm{g} \cdot \mathrm{l}^{-1}$ in Tokyo, Japan, up to $193 \mu \mathrm{g} \cdot \mathrm{l}^{-1}$ in Mexico City. The Tracy survey demonstrates the importance of factors such as age, gender, ethnicity, food, drinking and smoking habits, hobbies, season and year of sampling, residential area, and geographic location. Lead in blood was shown to be both time and area specific. Thus it was not possible to establish a general reference value for lead in blood.
\end{abstract}

Key terms inorganic lead.

Lead has many uses in society. World-wide emission of lead occurs through the use of leaded gasoline (1). Industrial emissions may also contribute, in some areas, to increased lead levels in air, food, and water. Lead has been a constituent in house paint in some countries (2). Furthermore, the use of lead pipes in fresh water systems and the use of lead-glazed household ceramics may substantially increase lead intake (3).

The absorption of lead from the gastrointestinal tract is about $10 \%$ in adults, but can be considerably higher in children (4). It increases when a person's diet is deficient in calcium and iron. In occupational settings, the main intake is through inhalation. Absorption through the respiratory tract is influenced by the size and solubility of the inhaled particles.

After absorption into blood plasma, lead is quickly taken up by the red blood cells, which contain about $99 \%$ of the lead in whole blood (5). Thus far, lead in whole blood $(\mathrm{B}-\mathrm{Pb})$ has been the main indicator medium used for the biological monitoring of humans. As an indicator of exposure and of internal dose, $\mathrm{B}-\mathrm{Pb}$ is a mandatory requirement for the biological monitoring of lead-exposed workers. This index has several advantages. Blood samples are easy to obtain, and the analysis is not partic- ularly complicated for experienced laboratories. The risk of contamination is negligible when evacuated tubes are used for sampling.

However, there are several limitations which must be kept in mind when $\mathrm{B}-\mathrm{Pb}$ values are interpreted. First, there is a nonlinear relationship between $\mathrm{B}-\mathrm{Pb}$ and lead exposure and uptake, irrespective of the route of uptake (6). Second, there is a nonlinear relationship between $\mathrm{B}-\mathrm{Pb}$, and lead in other indicator media, such as plasma, urine, and milk. Third, there is also a nonlinear relationship between different metabolic and toxic effects such as disturbed heme synthesis and $\mathrm{B}-\mathrm{Pb}$ (6). From the nonlinear relationship it follows that $\mathrm{B}-\mathrm{Pb}$ is a more sensitive index at low exposure levels as compared with high ones.

\section{Tracy project}

The Tracy project is an international project aimed at defining reference values for metal concentrations in adult human tissues and body fluids in populations without evidence of occupational or excessive environmental exposure so that populations with elevated exposure can be identified more precisely. The reference groups studied should preferably be in the age range from 20

1 Department of Occupational and Environmental Medicine, University Hospital, Lund, Sweden.

2 Imperial College of Science, Technology and Medicine, Centre for Environmental Technology, London, United Kingdom.

Reprint requests to: Dr Lars Gerhardsson, Department of Occupational and Environmental Medicine, University Hospital, S-221 85 Lund, Sweden. 
65 years and randomly selected from a larger population. Recently, the scope of the project has been widened to include the most essential and nonessential elements. In the course of the work by the Tracy group, tentative reference intervals have been presented, for example, for mercury (7) and chromium (8). A thorough description of the principles for the work of this expert group has recently been given by Vesterberg et al (9).

Several factors are of importance when reference intervals are evaluated for a certain element. According to the principles agreed upon by the Tracy group, each publication is graded and allocated into one of four categories given (zero to three stars) as to the quality of the sampling, analysis, and statistical treatment, including the presentation of the data. However, the grade given applies only to its usefulness in Tracy. Thus the paper evaluated could be of high quality from other points of view, even if it has been given a low grade in the Tracy evaluation (9).

Several factors are of great importance when reference values of $\mathrm{B}-\mathrm{Pb}$ in adults are studied. In the following discussion, these factors are further explained and exemplified under different subheadings related to sampling and analysis and in the format proposed as an aid to the standardization of evaluation (9).

\section{Sampling}

Numerous factors can affect B-Pb. Thus the country and district and grade of urbanization must be specified. In urban areas, $\mathrm{B}-\mathrm{Pb}$ is usually higher than in rural ones due to pollution from industries and traffic (4). The year of sampling can be related to the use of leaded or unleaded gasoline in a region.

$\mathrm{B}-\mathrm{Pb}$ is affected by factors such as age, gender, and ethnic origin. Levels in men are usually somewhat higher than in women (10). B-Pb also normally increases with age $(11,12)$. For proper statistical treatment of the data, it is preferable for the sample size to exceed about 40 subjects (9).

Lead intake from food and water has a great impact on $\mathrm{B}-\mathrm{Pb}$ in the general population $(4,13)$. Alcoholic beverages (eg, wine) may contain lead. The health status of the study population may also be of importance for $\mathrm{B}-\mathrm{Pb}$, since some herbal medicines, taken orally in some Asian countries, may contain lead.

Furthermore, smoking may be of importance, as tobacco contains lead. The lead content in a cigarette is $3-12 \mu \mathrm{g}$, and it has been estimated that about $2 \%$ of this amount is inhaled by the smoker (13). Smoking may also have an indirect effect by negatively affecting the mucociliary escalator.

Knowledge about possible occupational exposure is important as any such exposure is an exclusion criterion for blood lead reference values. Lead may be transferred to the home from lead-contaminated workplaces and give rise to elevated $\mathrm{B}-\mathrm{Pb}$ in household members who are not occupationally exposed (14). Certain hobbies, for example, indoor shooting, which often takes place during the winter period, may lead to raised $\mathrm{B}-\mathrm{Pb}$ concentrations (15). Other hobbies that must be taken into consideration include tin soldier molding (16), ceramic work with leadcontaining glazes (17), frequent long-distance jogging or cycling in areas with high environmental lead exposure (18), and motor sports connected to work with exhaust systems.

Procedures for contamination control and the transport and storage of samples before analysis are highly relevant for proper evaluation (19). Contamination can occur at every step from the sampling to the analysis. Contamination sources such as the subject's skin, sample containers, additives, reagents, and the analytical equipment must be considered (20). Even minor contamination from the skin or sampling equipment can lead to gross overestimation of the true B-Pb (21). Venous blood sampling from the antecubital vein is preferred for trace element analysis as compared with capillary blood sampling from the fingertip or ear.

Long-term storage of tissue samples, including reference materials, may lead to gradually decreasing metal concentrations. Therefore, regular checking for possible losses has to be undertaken. The storage temperature is important in this context. Thus a decrease in $\mathrm{B}-\mathrm{Pb}$ by about $20 \%$ in samples stored at $-20^{\circ} \mathrm{C}$ for four years has been claimed (22)

\section{Analysis}

A thorough description of the analytical method used to determine $\mathrm{B}-\mathrm{Pb}$ is important for a proper interpretation of the results. The term "quality assurance" refers to all steps undertaken to ensure that data are reliable; it includes the collection, transport and storage of samples, the laboratory analysis, and the recording, reporting and interpretation of the results. It also includes training and management designed to improve the reliability of the measurements (22). By keeping all sources of error on the lowest possible level, the total sum of errors for a data set may fall within previously established narrow acceptance limits. Some of these sources of errors may be discovered by means of external and internal quality control procedures using certified reference materials, interlaboratory comparisons, or an analysis of the same material by two independent analytical techniques (9).

The quality of the analytical results depends on the precision and accuracy of the method. The detection limit of the method also has to be clearly below the lowest concentrations that have to be determined.

Reference samples, or what is called external quality control samples, are used to test the accuracy of the results. These samples are available from several organizations, for example, NIST (National Institute of Stand- 
ards and Technology, Gaithersburg, Maryland, USA). The reference samples have to be of the same type or matrix and in the same concentration range as the measured samples.

It is important that reference samples be stable over long time periods and also at different temperature ranges. The results may also be checked by regularly including internal quality control samples with known $\mathrm{B}-\mathrm{Pb}$ concentrations,

\section{Data treatment}

Information about the underlying distribution of the data set (normal, log-normal or skewed), arithmetic or geometric mean, standard deviation or geometric standard deviation, or median value and range is highly relevant for proper evaluation of the values presented (9). The regression method has been used in the UNEP/WHO study on the assessment of human exposure to lead and cadmium $(23,24)$. This statistical method can discover systematic errors in the analytical process.

It is important that laboratories participating in quality assessment schemes present data on current method control, acceptance, and rejection criteria, together with the results of the $\mathrm{B}-\mathrm{Pb}$ determinations. It is not enough to refer to a particular method that has produced satisfactory results in an earlier study, perhaps at another laboratory several years ago (22). It is also important that reference samples be analyzed in parallel with the study samples to avoid problems with time trends.

\section{Material and methods}

Over 1000 papers published during the period 1980 to 1994 and presenting $\mathrm{B}-\mathrm{Pb}$ values of occupationally unexposed subjects have been identified using the Medline data base and personal contacts in the field of trace element analysis. Many of these papers refer to studies carried out in lead-contaminated environments, as, for example, in the vicinity of lead, zinc and copper smelters, and they include children with reference to, for example, their mental development. These studies show a wide range of $\mathrm{B}-\mathrm{Pb}$ values, particularly values related to time and sampling area.

The evaluation and grading of publications on $\mathrm{B}-\mathrm{Pb}$ values reported from studies on occupationally unexposed adult populations was performed by three independent investigators (LG, GK and AS). The publications were graded and categorized according to the Tracy criteria for sampling, analysis, and data treatment. With regard to their relevance for $\mathrm{B}-\mathrm{Pb}$ levels these criteria have been listed and described in the preceding sections. For the Tracy project, evaluators are required to use standard scoring procedures, to dichotomize the evalua- tion criteria into sampling (S) and analytical (A) categories, and to express the overall rating in terms of stars as indicators of the usefulness of publications for Tracy, where 0 indicates unsuitable, 1 acceptable, 2 good quality, and 3 excellent. It was stressed at the Tracy expert meeting in May 1992 that the rating could be of high quality from other points of view even if only a few stars are allocated for Tracy (9).

In this survey, 10 papers have been selected as examples of the criteria required for $\mathrm{B}-\mathrm{Pb}$ reference values. The selected papers have been given grades of 1 and 1 or higher for sampling and analysis, respectively, and are presented in table 1. This table shows the mean $\mathrm{B}-\mathrm{Pb}$ values and the given standard deviations or ranges for the populations. These 10 papers have been selected as examples and do not represent all publications which might be considered suitable for Tracy. It should be stressed that one of these 10 selected publications is given here only as an example of the effect on the $\mathrm{B}-\mathrm{Pb}$ level of workers in a lead-contaminated environment and is thus unacceptable for the Tracy project. The other nine papers are regarded as acceptable for Tracy and can be used as examples of tentative reference values for $\mathrm{B}-\mathrm{Pb}$ in adult men and women, exemplifying time trends, effects of geographic location, and life-style.

\section{Results}

In a global study of 200 school teachers (occupationally unexposed) from an urban area in each of 10 participating countries, the geometric mean $\mathrm{B}-\mathrm{Pb}$ levels varied from $60 \mu \mathrm{g} \cdot 1^{-1}$ in Tokyo, Japan, to $225 \mu \mathrm{g} \cdot 1^{-1}$ in Mexico City (24). In this study, the geometric mean B-Pb level for nonsmoking men in Tokyo was $65 \mu \mathrm{g} \cdot 1^{-1}$, and for current smokers it was $69 \mu \mathrm{g} \cdot 1^{-1}$, as compared with $52 \mu \mathrm{g} \cdot 1^{-1}$ and $64 \mu \mathrm{g} \cdot \mathrm{l}^{-1}$ for nonsmoking and smoking women, respectively. By comparison, in Mexico City, the values were $259 \mu \mathrm{g} \cdot 1^{-1}$ and $267 \mu \mathrm{g} \cdot 1^{-1}$ for men and $193 \mu \mathrm{g} \cdot 1^{-1}$ and $224 \mu \mathrm{g} \cdot 1^{-1}$ for women, respectively. In general, the men had higher $\mathrm{B}-\mathrm{Pb}$ values than the women and smokers had higher levels than nonsmokers. In the same study, nonsmoking women in Stockholm, Sweden, showed a geometric mean $\mathrm{B}-\mathrm{Pb}$ of $59 \mu \mathrm{g} \cdot \mathrm{l}^{-1}$. In two later studies by the same investigators in $1991(25,26)$, the mean $\mathrm{B}-\mathrm{Pb}$ for nonsmoking women had fallen to $29 \mu \mathrm{g} \cdot 1^{-1}$ and $30 \mu \mathrm{g} \cdot \mathrm{1}^{-1}$.

A similar decrease in the $\mathrm{B}-\mathrm{Pb}$ level over time was shown in a study by Elinder et al (27), with a fall in the mean B-Pb level of Stockholm inner city residents from $77 \mu \mathrm{g} \cdot \mathrm{l}^{-1}$ in 1980 to $52 \mu \mathrm{g} \cdot \mathrm{l}^{-1}$ in 1984 . The decrease was similar for the men and women, and other factors, such as age and change in residence during the study period, did not influence the results. In a study of the 
Table 1. Levels of lead in blood in reference populations. All values in micrograms per liter $\left(207 \mu \mathrm{g} \cdot \mathrm{I}^{-1}=\left.1.0 \mu \mathrm{mol} \cdot\right|^{-1}\right)$. The description of the criteria used for grading $(0-3$ stars $)$ is given in the text. ( $S=$ sampling, $A=$ analysis. $G M=$ geometric mean, GSD $=$ geometric standard deviation)

\begin{tabular}{|c|c|c|c|c|}
\hline Reference, grade S/A & $\begin{array}{l}\text { Number } \\
\text { of persons }\end{array}$ & Mean & SD & Range \\
\hline \multicolumn{5}{|l|}{ Friberg \& Vahter 1983 (24), grade 2/1 } \\
\hline \multicolumn{5}{|l|}{ Nonsmoking men } \\
\hline Brussels & 50 & $160(\mathrm{GM})$ & $1.3(\mathrm{GSD})$ & .. \\
\hline Beijing & 43 & 68 & & .. \\
\hline $\begin{array}{l}\text { Ahmedabad/India } \\
\text { Bancalore }\end{array}$ & 76 & 141 & 1.5 & ". \\
\hline $\begin{array}{l}\text { Bangalore } \\
\text { Calcutta }\end{array}$ & 9 & 224 & 1.4 & \\
\hline $\begin{array}{l}\text { Calcutta } \\
\text { Jerusalem }\end{array}$ & 31 & 110 & 1.7 &. \\
\hline Jerusalem & 92 & 89 & 1.4 & .. \\
\hline Tokyo & 17 & 65 & 1.3 & .. \\
\hline Mexico City & 21 & 259 & 1.3 & .. \\
\hline Lima/Peru & 12 & 111 & 1.3 & .. \\
\hline Stockholm & 31 & 75 & 1.6 & .. \\
\hline Baltimore & 24 & 83 & 1.4 & .. \\
\hline Zagreb & 30 & 129 & 1.4 & .. \\
\hline \multicolumn{5}{|l|}{ Nonsmoking women } \\
\hline Brussels & 39 & $119(\mathrm{GM})$ & 1.3 (GSD) & .. \\
\hline Beijing & 118 & 56 & 1.4 & .. \\
\hline Ahmedabad/India & 100 & 133 & 1.6 & .. \\
\hline Bangalore & 44 & 178 & 1.6 &.. \\
\hline Calcutta & 50 & 104 & 1.3 & .. \\
\hline Jerusalem & 51 & 64 & 1.6 &.. \\
\hline Tokyo & 77 & 52 & 1.3 & ." \\
\hline Mexico City & 33 & 193 & 1.3 & .. \\
\hline Lima/Peru & 89 & 92 & 1.2 & .. \\
\hline Stockholm & 45 & 59 & 1.6 &.$\cdot$ \\
\hline Baltimore & 64 & 62 & 1.4 &.$\cdot$ \\
\hline Zagreb & 84 & $7 \overline{6}$ & 1.5 &. \\
\hline \multicolumn{5}{|l|}{ Elinder et al 1986 (27), grade $2 / 1$} \\
\hline \multicolumn{5}{|l|}{ Residents of Stockholm } \\
\hline Sample from 1980 & 214 & 77 & 33 & .. \\
\hline Sample from 1983 & 113 & 54 & 33 & .. \\
\hline Sample from 1984 & 99 & 52 & 31 & .. \\
\hline \multicolumn{5}{|l|}{ Quinn \& Delves 1989 (28), grade 2/2 } \\
\hline \multicolumn{5}{|l|}{ English men } \\
\hline Sample from 1986 & 172 & $100(\mathrm{GM})$ &.. & .. \\
\hline \multicolumn{5}{|l|}{ English women } \\
\hline Sample from 1986 & 201 & 72 & .. & .. \\
\hline \multicolumn{5}{|l|}{ Vahter et al 1991 (25), grade $1 / 1$} \\
\hline \multicolumn{5}{|l|}{ Nonsmoking women } \\
\hline Beijing & 12 & 73 & 20 & .. \\
\hline Stockholm & 15 & 29 & 8 & .. \\
\hline Yokohama & 12 & 31 & 12 & .. \\
\hline Zagreb & 17 & 50 & 17 & .. \\
\hline \multicolumn{5}{|l|}{ Vahter et al 1991 (26), grade $1 / 1$} \\
\hline \multicolumn{5}{|l|}{ Nonsmoking female residents of Stockholm } \\
\hline Sample from 1988 & 15 & 30 & 8 & .. \\
\hline \multicolumn{5}{|l|}{ Grandjean et al 1992 (29), grade 2/1 } \\
\hline Male residents of Funen county, Denmark & 100 & 56 & 27 & .. \\
\hline $\begin{array}{l}\text { Consumers of alcohol } \\
\text { Nonconsumers of alcohol }\end{array}$ & $\begin{array}{l}64 \\
36\end{array}$ & $\begin{array}{l}60 \\
48\end{array}$ & $\begin{array}{l}29 \\
21\end{array}$ &.. \\
\hline Smokers & 58 & 58 & 29 & .. \\
\hline Nonsmokers & 41 & 52 & 27 & " \\
\hline Female residents of Funen county, Denmark & 100 & 46 & 29 & .. \\
\hline $\begin{array}{l}\text { Premenopausal women } \\
\text { Postmenopausal women }\end{array}$ & $\begin{array}{l}61 \\
39\end{array}$ & $\begin{array}{l}33 \\
62\end{array}$ & $\begin{array}{l}17 \\
35\end{array}$ &.. \\
\hline Smokers & 45 & 54 & 31 & .. \\
\hline Nonsmokers & 55 & 37 & 25 & .. \\
\hline \multicolumn{5}{|l|}{ Staessen et al $1992(30)$, grade $1 / 1$} \\
\hline \multicolumn{5}{|l|}{ Belgian men } \\
\hline Sample from 1985-1989 & 965 & $114(G M)$ & .. & $23-725$ \\
\hline \multicolumn{5}{|l|}{ Belgian women } \\
\hline Sample from 1985-1989 & 1016 & 75 & .. & $17-603$ \\
\hline
\end{tabular}


Table 1. Continued

\begin{tabular}{|c|c|c|c|c|}
\hline Reference, grade S/A & $\begin{array}{l}\text { Number } \\
\text { of persons }\end{array}$ & Mean & SD & Range \\
\hline \multicolumn{5}{|l|}{ Chao \& Wang $1994^{a}(14)$, grade $1 / 1$} \\
\hline $\begin{array}{l}\text { Exposed industrial workers from Taiwan } \\
\text { Unexposed industrial workers from Taiwan }\end{array}$ & $\begin{array}{l}41 \\
51\end{array}$ & $\begin{array}{r}204 \\
59\end{array}$ & $\begin{array}{l}94 \\
29\end{array}$ & $\begin{array}{l}. . \\
. .\end{array}$ \\
\hline \multicolumn{5}{|l|}{ Liou et al 1994 (31), grade $1 / 1$} \\
\hline Men and women from Taiwan & 2719 & 83 & 59 &. \\
\hline $\begin{array}{l}\text { Smokers } \\
\text { Nonsmokers }\end{array}$ & $\begin{array}{r}822 \\
1818\end{array}$ & $\begin{array}{l}89 \\
77\end{array}$ & $\begin{array}{l}65 \\
55\end{array}$ & $\begin{array}{l}. . \\
. .\end{array}$ \\
\hline $\begin{array}{l}\text { Men, nonsmokers } \\
\text { Women, nonsmokers }\end{array}$ & $\begin{array}{r}542 \\
1275\end{array}$ & $\begin{array}{l}88 \\
72\end{array}$ & $\begin{array}{l}59 \\
53\end{array}$ & $\begin{array}{l}. . \\
. \cdot\end{array}$ \\
\hline \multicolumn{5}{|l|}{ Ethnic groups from Taiwan } \\
\hline $\begin{array}{l}\text { Hakka } \\
\text { Mainlander } \\
\text { Fukien-Taiwanese }\end{array}$ & $\begin{array}{r}222 \\
191 \\
1379\end{array}$ & $\begin{array}{r}113 \\
80 \\
70\end{array}$ & $\begin{array}{l}77 \\
63 \\
49\end{array}$ & $\begin{array}{l}. . \\
. . \\
. .\end{array}$ \\
\hline \multicolumn{2}{|l|}{ Urban male runners from Genoa } & \multicolumn{3}{|c|}{ Orlando et al 1994 (18), grade $1 / 1$} \\
\hline Sample from 1989-1990 & 28 & 259 & 56 & .. \\
\hline $\begin{array}{l}\text { Rural male runners from Genoa } \\
\text { Rural male runners from Tortona } \\
\text { Male nonrunners from Genoa }\end{array}$ & $\begin{array}{r}10 \\
11 \\
182\end{array}$ & $\begin{array}{r}205 \\
83 \\
95\end{array}$ & $\begin{array}{l}60 \\
23 \\
46\end{array}$ & $\begin{array}{l}. . \\
. . \\
. .\end{array}$ \\
\hline
\end{tabular}

a Not suitable for the Tracy project because of occupational exposure.

general population in England, Quinn \& Delves (28) showed a progressive downward trend for the $\mathrm{B}-\mathrm{Pb}$ concentration over the period $1984-1987$ by $4-5 \%$ per year in all age groups, all social classes, and all categories of smoking and drinking habits, age of dwelling, and length of residence.

Grandjean et al (29) examined the B-Pb of 100 Danish men and 100 women in relation to age, smoking, and alcohol intake. In both groups, the $\mathrm{B}-\mathrm{Pb}$ increased with age, but for the women the tendency was also related to menstruation status, with a mean concentration of $33 \mu \mathrm{g} \cdot 1^{-1}$ in premenopausal women compared with $62 \mu \mathrm{g} \cdot 1^{-1}$ in postmenopausal women. For the total material, a significant increase in $\mathrm{B}-\mathrm{Pb}$ was related to alcohol consumption and to cigarette smoking. In this study, a higher $\mathrm{B}-\mathrm{Pb}$ was seen for urban residents than for rural ones. Multiple regression analysis showed alcohol consumption to be a significant predictor of the $\mathrm{B}-\mathrm{Pb}$ level of men, while menstruation status and cigarette smoking were significant predictors for women.

In a study of the general population in Belgium (30), the $\mathrm{B}-\mathrm{Pb}$ increased with age and was higher for the men than for the woman. For both genders, the $\mathrm{B}-\mathrm{Pb}$ increased with smoking and alcohol consumption. In this study, the $\mathrm{B}-\mathrm{Pb}$ showed regional differences and was lower in rural areas than in urban ones. A 10 -fold increase in $\mathrm{B}-\mathrm{Pb}$ was associated with a reduction of $10-$ $13 \mathrm{ml} \cdot \mathrm{min}^{-1}$ in creatinine clearance. It was concluded that, while lead exposure may impair renal function, the alternative hypothesis that renal impairment may lead to an increase in $\mathrm{B}-\mathrm{Pb}$ could not be excluded. The study illustrated the importance of ascertaining health status when $\mathrm{B}-\mathrm{Pb}$ reference levels are being determined.
Similar findings, with higher B-Pb levels in urban than in rural areas, have also been reported by Orlando et al (18) in a study of noncompetitive runners in northern Italy. The mean $\mathrm{B}-\mathrm{Pb}$ of a group of 28 runners, who trained in a large town (Genoa) with heavy traffic and high atmospheric lead levels, was $259 \mu \mathrm{g} \cdot \mathrm{l}^{-1}$. Lower values, mean $205 \mu \mathrm{g} \cdot \mathrm{l}^{-1}$, were found for a group of 10 runners from the same town, who trained mostly in a rural environment, and even lower values were found in a comparable group of 182 nonrunners, mean $95 \mu \mathrm{g} \cdot \mathrm{l}^{-1}$.

The impact of industrial emissions was exemplified in a study from Taiwan by Chao et al (14). In this study, the $\mathrm{B}-\mathrm{Pb}$ level of 41 workers (both genders) in a forging factory next to a lead recycling plant was significantly higher (mean $204 \mu \mathrm{g} \cdot \mathrm{l}^{-1}$ ) than that of a group of 51 workers (mean $59 \mu \mathrm{g} \cdot 1^{-1}$ ) from another forging factory, situated about $20 \mathrm{~km}$ from the lead plant. At the reference factory, the $\mathrm{B}-\mathrm{Pb}$ level was not related to gender. As potential lead sources, such as household activities and transportation, did not affect the $\mathrm{B}-\mathrm{Pb}$ at the forging factory next to the lead recycling plant, the major contribution would have been airborne emission from the latter. To reiterate, this study has been included to emphasize that it is necessary to investigate carefully the possibility of the presence of any lead emission source that may affect the $\mathrm{B}-\mathrm{Pb}$ of the persons intended for inclusion in reference groups. In many studies, reference groups are selected from the same workplace as the workers under investigation. Since they may have neighborhood exposure, they would be inappropriate as referents.

In a recently published comprehensive study from Taiwan (31), B-Pb was associated with several personal characteristics. The $\mathrm{B}-\mathrm{Pb}$ concentration was higher for 
the men than the women, and it increased with age, alcohol consumption and smoking, as well as with the degree of urbanization. On the other hand, $\mathrm{B}-\mathrm{Pb}$ was negatively associated with level of education and residential distance from roads. A clear difference was observed for the $\mathrm{B}-\mathrm{Pb}$ of the three ethnic groups in Taiwan. The highest concentrations were found for members of the Hakka group, followed by the Mainlanders and Fukien-Taiwanese (values for nonsmokers given in table 1). These three ethnic groups have different food habits, which may explain the observed difference. Hakka Chinese, for example, typically consume salted vegetables prepared in lead glazed containers. Use of salt and acidic conditions may cause leakage of lead from such containers and therefore probably increases the peroral intake in this population. In this study, B-Pb was also influenced by the intake of water. Persons drinking bottled water, well water, or spring water had higher levels than persons drinking tap water. This study indicates that ground water, especially in the southern part of Taiwan, may have been polluted, for example, by industrial emissions of lead.

\section{Discussion}

The studies summarized in table 1 illustrate the outcome when criteria specified by the Tracy group as being a necessary requirement for reference levels of $\mathrm{B}-\mathrm{Pb}(9)$ are applied to several reports on this subject.

While in all the scrutinized studies an arithmetic or geometric mean or median and standard deviation or range were presented, the distribution type was in most cases not adequately reported.

At the meeting of the Tracy group held in Nice, in 1993 , it was agreed that for tentative reference values for $\mathrm{B}-\mathrm{Pb}$, two essential criteria with regard to the analytical procedure were participation in an interlaboratory comparison program and the use of certified reference materials of the same matrix and of a similar concentration range as the real samples. For the time being, however, no certified reference blood samples with certified lead concentrations at "normal levels" are available. Accordingly, these two criteria could not be fulfilled.

Nowadays, no absolute analytical method is available that guarantees accurate results under all circumstances. Without information about the use of proper quality assurance programs, the quality of the data can be questionable even if the concentration ranges presented fall within an interval that seems reasonable.

Because $\mathrm{B}-\mathrm{Pb}$ is influenced by numerous factors, varying with the place and time of sampling, it is not possible to present general international reference values for $\mathrm{B}-\mathrm{Pb}$. Due to geographic and ethnic differences, such values are area specific, as is exemplified in this survey. Sometimes these values may be valid for a minor geographic region only and sometimes for a larger region, such as a country. As the lead exposure sources are constantly changing, for example, the decreasing use of leaded gasoline in many countries, reference values are also restricted to certain time periods. In southern Sweden, the $\mathrm{B}-\mathrm{Pb}$ (geometric mean) of schoolchildren has decreased from about $60 \mu \mathrm{g} \cdot 1^{-1}$ in 1978 to about $25 \mu \mathrm{g} \cdot 1^{-1}$ during a period of about 15 years $(1,32)$. The change from leaded to unleaded gasoline has probably played a dominant role in this context. During the same period, however, the use of lead-soldered cans and leadglazed ceramics has also decreased in Sweden. A parallel decrease of airborne lead exposure from other countries is another factor that can have influenced the blood lead levels.

The studies presented in this survey represent only a very small part of all recent papers on $\mathrm{B}-\mathrm{Pb}$ in reference populations. However, they exemplify some of the factors that are important when trying to define reference values for $\mathrm{B}-\mathrm{Pb}$ in reference populations. In the future, evaluation criteria such as those adopted by the Tracy group must be more generally used. Scientific journals have a responsibility to encourage authors to increase the quality of published data in this direction.

\section{Acknowledgments}

In the course of this work, valuable contributions to the project have been given by Antero Aitio, Finland; Lorenzo Alessio, Italy; Dag Brune, Norway; Rita Cornelis, Belgium; Robert Herber, The Netherlands; Ian Kucera, Czech Republic; Per Leffler, Sweden; Jean Neve, Belgium; Gunnar Nordberg, Sweden; Monica Nordberg, Sweden; Enrico Sabbioni, Italy; Olof Vesterberg, Sweden.

\section{References}

1. Schütz A, Attewell R, Skerfving S. Decreasing blood lead in Swedish children, 1978- 1988. Arch Environ Health 1989; 44:391-4.

2. Chisolm JJ Jr. Management of increased lead absorption illustrative cases. In: Chisolm JJ Jr, O'Hara DM, editors. Lead absorption in children: management, clinical and environmental aspects. Baltimore, Munich: Urban \& Schwarzenberg, 1982:171-88.

3. US Environmental Protection Agency (EPA). Air quality criteria for lead. Research Triangle Park (NC): EPA, Environmental Criteria and Assessment Office, 1986. EPA-600/8$83 / 028 \mathrm{aF}$, vol I-IV.

4. Skerfving S. Biological monitoring of exposure to inorganic lead. In: Clarkson TW, Friberg L, Nordberg GF, Sager PR, 
editors. Biological monitoring of toxic metals. New York (NY): Plenum Press, 1988:169-97. Rochester series on environmental toxicity.

5. Schütz A, Bergdahl IA, Ekholm A, Skerfving S. ICP-MS determination of lead in plasma and whole blood in lead workers and referents. Occup Environ Med. In press.

6. Skerfving S, Nilsson U, Schütz A, Gerhardsson L. Biological monitoring of inorganic lead. Scand J Work Environ Health $1993 ; 19$ suppl 1:59-64.

7. Brune D, Nordberg GF, Vesterberg O, Gerhardsson L, Wester $\mathrm{PO}$. A review of normal concentrations of mercury in human blood. Sci Total Environ 1991;100:235-82.

8. Brune D, Aitio A, Nordberg G, Vesterberg $O$, Gerhardsson L. Normal concentrations of chromium in serum and urine - a TRACY project. Scand J Work Environ Health 1993;19 suppl $1: 39-44$.

9. Vesterberg O, Alessio L, Brune D, Gerhardsson L, Herber R, Kazantis $\mathrm{G}$, et al. Intemational project for producing reference values for concentrations of trace elements in human blood and urine - TRACY. Scand J Work Environ Health 1993;19 suppl 1:19-26.

10. Staessen J, Yeoman WB, Fletcher AE, Markowe HLJ, Marmot MG, Rose $\mathrm{G}$, et al. Blood lead concentration, renal function, and blood pressure in London civil servants. $\mathrm{Br} \mathrm{J}$ Ind Med 1990;47:442--7.

11. Mahaffey KR, Annest JL, Roberts J, Murphy RS. Nationa1 estimates of blood lead levels: United States, 1976-1980: association with selected demographic and socioeconomic fac. tors. N Engl J Med 1982;307:573-9.

12. Ducoffre G, Claeys F, Bruaux P. Lowering time trend of blood lead levels in Belgium since 1978. Environ Res 1990;51: $25-34$.

13. Tsuchiya K. Lead. In: Friberg L, Nordberg GF, Vouk VB, editors. Handbook on the toxicology of metals. Amsterdam; Elsevier, 1986:298-353. Specific metals, vol II.

14. Chao K-Y, Wang J-D. Increased lead absorption caused by working next to a lead recycling factory. Am J Ind Med 1994; $26: 229-35$

15. Svensson BG, Schütz A, Nilsson A, Skerfving S. Lead exposure in indoor firing ranges. Int Arch Occup Environ Health 1992:64:219-21.

16. Schütz A, Ranstam J, Skerfving S, Tejning S. Blood-lead levels in school children in relation to industrial emission and automobile exhausts. Ambio 1984;13:115-7.

17. Mendéz JH, de Blas OJ, del Valle González A. Correlation between lead content in human biological fluids and the use of vitrified earthenware containers for foods and beverages. Food Chem 1989;31:205-13.

18. Orlando P, Perdelli F, Gallelli G, Reggiani E, Cristina ML, Oberto $\mathrm{C}$. Increased blood lead levels in runners training in urban areas. Arch Environ Health 1994;49:200-3.

19. Aitio A, Järvisalo J. Biological monitoring of occupational exposure to toxic chemicals: collection, processing, and storage of specimens. Ann Clin Lab Sci 1985;15:121 -39.

20. Aitio A. Biological monitoring. In: Biological monitoring of toxic metals. Clarkson TW, Friberg L, Nordberg GF, Sageı PR, editors. New York (NY): Plenum Press, 1988:75-83. Rochester series on environmental toxicity.

21. Flegal AR, Smith DR. Current needs for increased accuracy and precision in measurements of low levels of lead in blood. Environ Res 1992;58:125-33.

22. Friberg L. Quality assurance. In: Clarkson TW, Friberg L, Nordberg GF, Sager PR, editors. Biological monitoring of toxic metals. New York (NY): Plenum Press, 1988: 103126. Rochester series on environmental toxicity.

23. Vahter M. Assessment of human exposure to lead and cadmium through biological monitoring. Prepared for the UNEP and WHO by the National Swedish Institute of Environmental Medicine and Karolinska Institute (Department of Environmental Hygiene), Stockholm, 1982:1-136.

24. Friberg L, Vahter M. Assessment of exposure to lead and cadmium through biological monitoring: results of a UNEP/ WHO global study. Environ Res 1983;30:95-128.

25. Vahter M, Berglund M, Slorach S, Friberg L, Saric M, Xingquan Z, et al. Methods for integrated exposure monitoring of lead and cadmium. Environ Res 1991;56:78-89.

26. Vahter M, Berglund M, Lind B, Jorhem L, Slorach S, Friberg L. Personal monitoring of lead and cadmium exposure - a Swedish study with special reference to methodological aspects. Scand J Work Environ Health 1991;17:65-74.

27. Elinder C-G, Friberg L, Lind B, Nilsson B, Svartengren M, Övermark I. Decreased blood lead levels in residents of Stockholm for the period 1980-1984. Scand J Work Environ Health $1986 ; 12: 114-20$.

28. Quinn MJ, Delves HT. The UK blood lead monitoring programme 1984-1987: results for 1986. Human Toxicol 1989;8:205-20.

29. Grandjean P, Nielsen GD, Jorgensen PJ, Horder M. Reference intervals for trace elements in blood: significance of risk factors. Scand J Clin Lab Invest 1992;52:321-37.

30. Staessen JA, Lauwerys RR, Buchet J-P, Bulpitt CJ, Rondia D, Vanrenterghem $Y$, et al. Impairment of renal function with increasing blood lead concentrations in the general population. N Engl J Med 1992;327:151-6.

31. Liou SH, Wu TN, Chiang HC, Yang GY, Wu YQ, Lai JS, et al. Blood lead levels in the general population of Taiwan, Republic of China. Int Arch Occup Environ Health 1994;66: $255-60$.

32. Strömberg U, Schütz A, Skerfving S. Substantial decrease of blood lead in Swedish children, 1978-94, associated with petrol lead. Occup Environ Med 1995;52:764-9.

Received for publication: 17 June 1996 